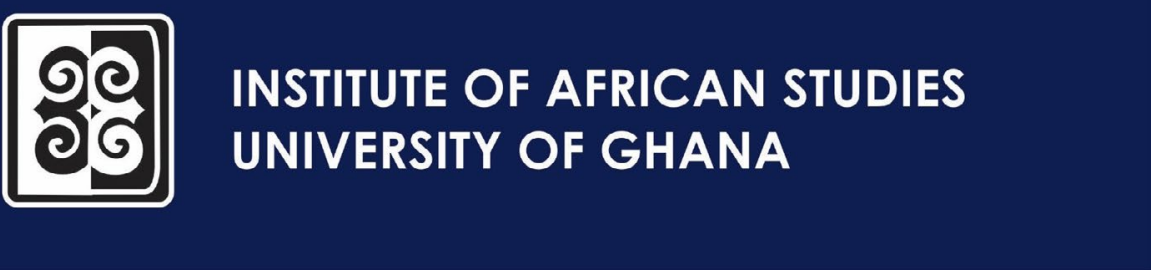

Contemporary Journal of African Studies 2020; 7 (1): 116-122

https://dx.doi.org/10.4314/contjas.v7i1.8

ISSN 2343-6530

(C) 2020 The Author(s)

Open Access article distributed under the terms of the

Creative Commons License [CC BY-NC-ND 4.0]

http://creativecommons.org/licenses/by-nc-nd/4.0

\section{Restitution and return of looted royal heritage: the role of Ghanaian chiefs and queens in sustaining heritage traditions}

\section{Mamaga Ametor Hoebuadzu II ${ }^{1} \&$ Togbui Opeku VI ${ }^{2}$}

\section{${ }^{1}$ Paramount Queen, Alavanyo Traditional Area}

Authoremail: ametorilm@gmail.com

\section{${ }^{2}$ Chief, Kpando-Agbenohoe}

Author email: kentogbe@gmail.com

\section{Abstract}

In interrogating this discourse on the restitution and return of looted royal objects, our role and input in this conversation as traditional leaders in Ghanaian communities are inevitable. This is in the light of the fact that the source of most of these looted royal art objects unlawfully placed in German and some European museums are from the Volta Basin area of Ghana, formerly part of German Togoland. We argue that factoring in the views of chiefs and queens, being traditional leaders of communities in Africa, provides a better understanding of the origin and contexts of the use of most of these pirated cultural objects highlighted in the restitution and repatriation debates.

Keywords: African chiefs and queens, custodians of indigenous cultures and traditions, restitution 


\title{
Restitution and Return of Looted Royal Heritage: The Role of Ghanaian Chiefs and Queens in Sustaining Heritage Traditions.
}

\author{
Mamaga Ametor Hoebuadzu II and Togbui Opeku VI
}

\begin{abstract}
In interrogating this discourse on the restitution and return of looted royal objects, our role and input in this conversation as traditional leaders in Ghanaian communities are inevitable. This is in the light of the fact that the source of most of these looted royal art objects unlawfully placed in German and some European museums are from the Volta Basin areas of Ghana, formerly part of German Togoland. We argue that factoring in the views of chiefs and queens, being traditional leaders of communities in Africa, provides a better understanding of the origin and contexts of the use of most of these pirated cultural objects highlighted in the restitution and repatriation debates.
\end{abstract}

Keywords: African Chiefs and Queens, custodians of indigenous cultures and traditions, restitution.

\section{https://dx.doi.org/10.4314/contjas.v7i1.8}

Mamaga Ametor Hoebuadzu II (ametorilm@gmail.com) is Paramount Queen of Alavanyo Traditional Area, and founder of Volta Young Queens Club. Mamaga was installed on 15th January, 2006 at Alavanyo Kpeme as the Paramount Queen of Alavanyo Traditional Area. Known in private life as Barbara Peace Atiboly, She is a product of Peki Secondary School, Kpando Technical Institute and Pan-African Institute of Management. She holds a Bachelor of Science degree in Banking and Finance from Kings University College, Accra. Besides pursuing short courses in Kenya (Gender and Development) and India Bhubaneswar, Odisha (Working Capital Management), Mamaga has an MPhil degree in Leadership and Certificate in International Relationship and Diplomacy from GIMPA, Ghana.

Togbe Opeku VI (kentogbe@gmail.com) has been the Chief of Kpando-Agbenohoe for the past sixteen years. He is also the Chief overseeing the Paramount Chief Palace of Kpando until a substantive Dagadu is enstooled. He is known in private life as Kenneth Affor. He is a product of the College of Accountancy, Kpando. Until his retirement from the Public Service of Ghana, he was Assistant Manager of the Social Security and National Insurance Trust. Togbui is well versed in chieftaincy and heritage issues in Kpando, the Volta Region and in Ghana as a whole. 


\section{Résumé}

En interrogeant ce discours sur la restitution et le retour des objets royaux pillés, notre rôle et notre contribution à cette conversation en tant que chefs traditionnel des communautés ghanéennes sont indispensables. En effet, la source de la plupart de ces objets d'art royaux pillés, placés illégalement dans des musées allemands et certains musées européens, se trouve dans les régions du bassin de la Volta au Ghana, qui font officiellement partie du Togoland allemand. Nous soutenons que l' intégration des points de vue des chefs et des reines, qui sont les chefs traditionnels des communautés en Afrique, permet une meilleure compréhension de l' origine et des contextes d'utilisation de la plupart de ces objets culturels piratés dans les débats sur la restitution et le rapatriement.

Mots-clés: Chefs et reines d'Afrique, gardiens des cultures et traditions indigènes, restitution.

\section{Introduction}

In interrogating this discourse on the restitution and return of looted royal objects, our role and input as traditional leaders in Ghanaian communities are inevitable. The source of most of these looted royal art objects unlawfully placed in German and some European museums are from the Volta Basin areas of Ghana, formerly part of German Togoland. Factoring in the views of chiefs and queens, being traditional leaders of communities in Africa, provides a better understanding of the origin and contexts of the use of most of these pirated cultural objects highlighted in the restitution and repatriation debates. As legitimately enstooled or enskinned leaders of indigenous communities, chiefs and queens are expected to be the custodians of communities' sacred and mundane cultural objects. The scope of our work and its implications for providing productive agency to the debate and being the eventual recipient of some of the returned objects and human remains must not be silenced but cherished. This stance undergirds our discussion in the ensuing sections.

\section{Ghanaian Chiefs and Queens as Custodians of Cultural Heritage Traditions}

The roles and values of Ghanaian traditional leaders in preserving and transmitting cultural traditions and objects have stood the test of time. This assertion is reaffirmed in Otumfuo Osei Tutu II, the king of the Asante kingdom, claims that, "I am the occupant of a sacred stool that embodies the heritage of a great and proud people. The history of the Golden Stool and the Asante kingdom spans over four hundred centuries over which a system of governance evolved that stood the test of time" (2014: 226). Furthermore, he alluded to the custodial and judicial roles 
traditional leaders play by pointing out that "apart from our role as the custodians of the land, we are the primary arbiters in the resolution of conflict on daily basis and helping to maintain peace and order at all levels" (2014: 224). This contention implies that the powerful and respected authority of traditional leaders and their sacred palaces make their interventions in ameliorating the adverse effects of conflicts a very meaningful aspect of African cultural values.

Such authority, power and respect can be easily compromised when traditional leaders lack the necessary legitimacy that are enhanced by the availability of the relevant material heritage that serves as the spiritual foundation of that chieftaincy. This often happens when enthroned chiefs and queens are not the rightful heirs to the throne. However, in the past, colonial authorities destabilized the legitimacy of traditional leaders by raiding their palaces to confiscate some of these sacred objects which were often seen as an affront to the western authoritarian powers.

\section{Putting Royal Heritage in Cultural and Historical Perspectives}

Relics of our heritage, whether in the form of buildings, carvings, sculptures, utensils and indeed royal items currently being used such as state swords, stools, royal skins, crowns, and palanquins among others are of paramount importance to the study of our societies. These physical items, as huge as the pyramids of Egypt or as minute as an ordinary bead that societies leave behind, point to the nature of the people's culture and way of life and constitute the primary evidence in the study of human societies.

Archaeologists and art historians have largely relied on these objects to tell the stories of societies and their way of life. Some of these societies are extinct yet these items have lived on over the years to tell their stories. Anthropologists have relied on these findings to help close generational gaps which has helped to settle disputes and other issues regarding inheritance. This means that the importance of such items cannot be belittled or over emphasised. Every culture has cultural regalia and symbols which signify their uniqueness. Our unique cultures, as exemplified in the cloths, crowns, stools, skins, drums and trumpets we use could immediately tell where we come from. Our experience of losing these very important items to Europeans is one of pain, anguish and a taboo. This is because they constitute the very soul of our societies for without them our history cannot be fully told. It also brings to mind the sufferings that our ancestors endured at the hands of Europeans during the ignominious slave trade and colonial periods with their associated evil histories. There is the need to note that the loss of the ingenuities and indigenous knowledge systems of our ancestors through their cherished art works and other heritages, has been a big blow to the growth and development of many of our societies. 


\section{The Value of Royal Material Culture}

As custodians of the Alavanyo and Kpando-Agbenoxoe stools and royal traditions in Ghana respectively, we know the royal heritage of our respective communities, including our royal stools and the institutions of our offices as a Queen (or Female Chief) and Chief, respectively. This means that we live and practice our customs and traditions every day. Imagine if any one of these assemblages of things we consider as our royal heritage, for example, the royal stools, palanquins, talking drums, trumpets, crowns, jewelleries, umbrellas, linguist staffs is looted, what will become of our royal institutions or what will be our legacy to our successors? Such a loss or losses can lead to many disastrous consequences in the communities we serve. First, some routine rituals cannot be performed; this means that the indigenous knowledge and traditions associated with this royal obligation will slowly die out and be lost forever. The traditional power and potency of these royal objects will also be reduced and rendered meaningless when they are kept in non-functional states in European museums. The traditional channels through which chiefs and queens assemble and communicate with their people will also break down due to the loss of such royal objects (e.g., talking drums, gong-gongs and royal horns). Second, the oath that we took to protect the legacies of our forebears will now be reneged upon. In such a scenario, we are likely to suffer the spiritual and social calamities associated with the loss of these legacies.

As custodians of our traditions, we have a duty to relay the essence of our traditions and cultures to generations yet unborn. This duty is not limited to our verbal narrations alone, but they must be supported with physical royal items which serve as living testimonies to the stories we pass on. Without these objects, the process of teaching the next generation about the significance of these objects and associated cultural performances will be lost. This creates a recipe for cultural disaster, which will invariably lead to the termination of the continuity and sustainability of that royal identity and for that matter, our identity as a people. The youth will subsequently yield to the learning and adoption of negative aspects of foreign and alien cultural practices, a shift already emerging in Ghanaian societies today.

The lesson learnt and the real issue at hand is that royal heritage and chieftaincy institutions in Ghana are vital institutions that hold a community together. The royal material cultures that make up our heritage are essential elements that make the institution workable, implementable and holistic. Thus, the loss of one becomes a tragedy to our heritage and our societies. The roles that traditional Queens or Chiefs play take their source from that holistic foundation of their royal institutions (Kludze 2012). For example, the role of the Queen in heritage education in a society is akin to how a hen leads its chicks through life against the odds of the claws of the hawk, floods and throats of serpents. 


\section{Need for Restitution of Looted Royal Objects}

Our understanding of cultural objects is based on our experiences with royal regalia and the institution of chieftaincy that we serve. We are thus well placed to offer our perspective on the restitution debates. We are also well placed to receive returned royal objects and subject them to the necessary traditional cleansing that they need to undergo to be integrated into our royal regalia; if that is what has to be done. For example, one of the authors of this paper who is the chief of Kpando-Agbenoxoe and the Keeper of the Kpando Royal Palace, has been deeply concerned about how Akpini royal objects are being kept in German museums as if they were slaves or prisoners without owners.

The Akpini people are the indigenous people of Kpando and they speak Ewe. This chieftaincy institution has endured through migration from Notsie in the seventeenth century through the periods and impacts of many other episodes such as Akwamu and Asante imperialist territorial expansion into the area, followed by British and German colonial incursions before independence and the kingdom's integration into Ghana. Accounts of some powerful chiefs engaging in the slave trade notwithstanding, it must be made clear here that the chieftaincy institution and some chiefs were direct victims of the slave trade and the heinous practices of colonization. It is on record that some chiefs were hanged, gunned down and slaughtered as a result of their resistance to the slave trade and colonization. Dzidzienyo and Nkumbaan's paper in this volume provides some historical case studies to buttress this point. So, in actual fact, it is not only cultural materials that were lost to European museums; human skeletons and remains of royals were also taken away. The return of the head of King Bonsu exemplifies this point. How many more of such skeletal remains, especially, originating from the Volta Basin are held up in European museums and laboratories awaiting discovery and return?

Yet, despite the negative impacts of all these foreign dominations, the chieftaincy institution in Kpando has been sustained and maintained intact to the present. What sustains it, however, is the adherence to customary law, Akpini and Alavanyo cultural practices, the use of cultural objects and the traditional technology and knowledge systems. During the periods of the formation of the Akpini state, a number of traditions and cultural objects were created based on their historical exigency (Apoh 2019). The Akpini state developed and added to those received from the ancestors. Thus, every object and cultural or ritual practice has a history which is integral to the identity of the Akpini people today. It is thus crucial to note that when a cultural object is lost or looted, a significant part of our history is also lost with it. What remains is a memory. When that memory fades out of the oral history then that cultural object, its traditions, its performances and its relevance to the people are also lost forever. 
Apoh and Mehler's introductory paper in this volume makes mention of some Akpini royal objects that were looted from the Kpando royal palace in 1914 by a German colonial agent called Dr Grunner. During the arrest of King Dagadu III in the Kpando palace and his exile to Cameroon on false charges, the royal objects including drums, ivory side-blown horns, smocks and other items were looted. Some of these objects are in the Ethnologishes Museum in Berlin (Apoh 2019). In 2015, the late Chief Togbe Dagadu VIII, accompanied by Professor Apoh, made a request to the previous German Ambassador at his Embassy in Accra for these objects to be returned. The people of Kpando are yet to receive the written response to this request. They are also hopeful to see the return of these unique royal objects of the Akpini people to satisfy historical justice. It is also the fundamental cultural rights of the Akpini people to have access to their royal heritage and cultural objects. As sacred royal items, in the event that these objects are returned, the chiefs and elders of Kpando possess the traditional knowledge on how to cleanse and reintegrate them into our cultural performances. The traditional leaders also have the right to subject them to any process and to make them available to the public in a community museum or not.

\section{Conclusion}

We would like to end by thanking the organizers of the restitution workshop and editors of this volume for adding our voice to the debate to give us agency. We also cherish the fact that they are focusing on the need to return the numerous stolen African cultural, ritual and royal objects back to their owners. Our cultural institutions, knowledge systems, indigenous identity and royal traditions and cultural education cannot be sustained for the next generation if we fail to protect, conserve and practice these good cultural values that we inherited from our ancestors though the royal objects. We also wish to add our voices to state that the calls for the return and restitution of Africa's looted cherished royal regalia and other unique items are in the right direction and we fully support them. If we want to fully tell our story and leave some legacy for our descendants, then all must support this call, for the time is now. 


\section{References}

Apoh, W. (2019). Revelations of Domination: Discovering the Buried Past of the Akpinis, Akans, Germans and British at Kpando, Ghana. Accra: SubSaharan Publishers

Kludze, A. K. P. (2012). Ewe Law of Property. Second Edition. Accra: Sonlife Press

Leijten, M. H. (2015). From idol to art: African 'objects with power': a challenge for missionaries, anthropologists and museum curators. Leiden: African Studies Centre

Otumfuo O. T. II. (2014). Traditional leadership in Africa's Democratic Transition. In Agyeman-Duah, I and Ogochukwu, P. (Eds.) Crucible of the Ages: Essays in Honour of Wole Soyinka at 80. Ibadan: Bookcraft. 